\title{
Development of a universal gap repair vector for yeast-based screening of knockout rodents
}

\author{
Kai-Shun Chen and Michael N. Gould \\ University of Wisconsin Medical School, Madison, WI, USA
}

BioTechniques 37:383-388 (September 2004)

Recently, we reported the production of the first knockout rats by combining $N$-ethyl-Nnitrosourea (ENU)-induced mutagenesis with a yeast-based truncation screening method. To make this new knockout technology more applicable for other laboratories and for highthroughput applications, we have developed a universal gap repair vector that is ready for use in screening for gene knockouts without additional engineering. The universal gap repair vector was validated for its application in both cDNA- and genomic DNA-based yeast truncation mutation assays. Breast cancer genes Brca1, Brca2, and Adenomatosis polyposis coli (Apc) genes from $\mathrm{N} 2$ rats of Brca1 and $\mathrm{Brca} 2$ knockouts and $\left(\mathrm{Atm} \times \mathrm{Apc}^{\mathrm{Min} /+}\right)$ F1 mice were examined, respectively. The results indicate that the universal gap repair vector we developed, using randomly selected codons as a universal cassette, is equally efficient at identifying truncation mutations as are those gap repair vectors designed specifically for Brca1 and Brca2. The availability of a universal gap repair vector should facilitate the broader screening of knockouts of most genes of many species using the combined approach of ENUinduced mutagenesis and yeast truncation assay.

\section{INTRODUCTION}

Mouse embryonic stem cell-based knockout technology has been available for more than a decade. However, a similar technology is not available for another important rodent model: the rat. All attempts to generate embryonic stem cell-based rat knockouts have thus far been unsuccessful. Recently, we have reported the generation of the first knockout rats using an alternative approach (1). N-ethyl-N-nitrosourea (ENU) has been demonstrated to be the mutagen of choice for the production of heritable altered phenotypes in mice $(2,3)$. Although high-efficiency sequencing methods are available for the screening of ENU-induced mutations in genomic DNA and cDNA, less than $10 \%$ of the ENU-induced mutations identified are likely to be functional mutations (2). The yeast truncation assay can efficiently sort out functional mutations from nonfunctional ones, avoiding much unnecessary downstream characterization of nonfunctional mutations. By combining ENUinduced mutagenesis in the rat with a yeast-based functional mutation assay, we successfully produced knockout rats for the breast cancer suppressor genes Brcal and Brca2 (1). In brief, male rats were mutagenized by ENU treatment and bred with wild-type females. DNA and total RNA were isolated from tail clips of F1 rats. Genomic DNA and cDNA fragments of selected genes, Brcal and Brca2, were amplified by PCR or reverse transcription PCR (RT-PCR) and cloned by co-transformation with a specific corresponding gap vector into yeast cells. Truncation mutations of these gene fragments were identified by color screening of yeast colonies on selective media. For each gene fragment we screened, a corresponding gap repair vector was engineered to contain a cassette of two approximately $100 \mathrm{bp}$ half sites of that particular gene fragment. The construction of gene-specific or gene fragmentspecific gap repair vectors is a laborintensive process, particularly when a large number of genes are screened simultaneously. To make this technology more applicable for high-throughput screening, it is necessary to develop a universal gap vector. An ideal universal gap repair vector should allow for the screening of any gene of interest without the need for further engineering. In this paper, we describe the generation and characterization of such a univer- 
Table 1. Sequences of Oligonucleotide Primers

\begin{tabular}{|c|c|}
\hline Primer & Sequence \\
\hline L306-hyb-rBrca1UP3982a & 5'-GGCCATCGATAGCTCGATGTAACGTGCAGTTAACGCCCCAGGCTGAGAATGAGGAAGC-3'c \\
\hline L306-hyb-rBrca1UP5038 & 5'-GGCCATCGATAGCTCGATGTAACGTGCAGTTAACGCCCTTTGTGTGTGAACGGACACTGA-3' \\
\hline Brca1 LP5593 & 5'-GACGGGAAGACCATTTCT-3'c \\
\hline L306-hyb-rBrca2UP3436 & 5'-GGCCATCGATAGCTCGATGTAACGTGCAGTTAACGCCCCATAACTTAACGCCCAGCCAAA-3' \\
\hline L306-hyb-rBrca2LP5265 & 5'-GGCCTACTAACAGATACGCTATGCAGGACTCTGGATTGCCCGGCATTTCCTGCAAAATCT-3' \\
\hline L306-hyb-mApcLP3129 & 5'-GCCTACTAACAGATACGCTATGCAGGACTCTGGATTGCCCCTGTGAGGGACTCTGCCTTC-3'd \\
\hline Brca2 LP6331 & 5'-TCAАATTССТСТААСАТТССТ-3' \\
\hline \multicolumn{2}{|c|}{$\begin{array}{l}\text { Hybrid oligonucleotide primers are designed so that the PCR product contains an open reading frame in phase with the } 5^{\prime} \text { leader sequence and the } 3^{\prime} \text { Ade2 reporter } \\
\text { gene after homologous recombination with the universal gap repair vector. UP stands for the upper primer, and LP stands for the lower primer in naming the oligo- } \\
\text { nucleotides. The number following "UP" or “LP" represents the starting position of the oligonucleotide in its corresponding cDNA. } \\
\text { aL306 series upper chimeric oligonucleotides containing upper L306-linker half-site sequences (underlined). } \\
\text { bL306 series lower chimeric oligonucleotides containing lower L306-linker half-site sequences (bolded and italicized). } \\
\text { cGene specific sequence by itself or in chimeric primers is in black. Brca1 has two upper primers to be used with the lower primer. } \\
\text { dThe linker sequences in some lower hybrid primers are trimmed at their } 5^{\prime} \text { termini to limit the combined sequence to } 60 \text { bases. }\end{array}$} \\
\hline
\end{tabular}

sal vector and verify its ability to detect mutations in two different species.

\section{MATERIALS AND METHODS}

\section{Construction of Universal Gap Repair Vectors}

The backbone vector pLSK870 (GenBank ${ }^{\circledR}$ accession no. AY297714; Reference 1) used for generating genespecific gap repair vectors was also used to construct the universal gap repair vector. The universal cassette consisted of two half sites of randomly selected codons linked by a SmaI site (Figure 1). The compiled universal cassette sequences were compared with the rat genome and pLSK870 vector sequences using the National Center for Biotechnology Information (NCBI) Basic Local Alignment Search Tool (BLAST)2 Sequences (4) to eliminate any sequences with a long stretch of high homology. To justify a more general application of the universal gap repair vector, we compared the universal cassette of the randomly selected codons with the database of all GenBank+EMBL+DDBJ_PDB sequences [including expressed sequence tag (EST), sequence-tagged site (STS), genome survey sequence (GSS), and phase 0,1 , and 2 high-throughput genomic sequences (HTGS)]. No long stretches ( $>19$ bases) of high homology to known or expressed sequences of any species were identified in our BLAST search.

Complementary universal linker oligonucleotides, each at a concentration of $100 \mu \mathrm{M}$, were annealed in 10 $\mathrm{mM}$ Tris-HCl, pH 7.6, 25 mM NaCl, 1 $\mathrm{mM}$ EDTA by heating in a heat block at $75^{\circ} \mathrm{C}$ for $40 \mathrm{~min}$ and then cooling slowly to $4^{\circ} \mathrm{C}$. The pLSK870 backbone plasmid was digested with NotI to completion and examined by electrophoresis. The annealed universal cas- settes were cloned into the pLSK870 vector at the NotI site to generate universal gap repair vectors. The universal gap repair vector containing the cassette of random codons was designated as pLSL306. Recombinant universal gap repair vector clones were identified by SmaI digestion of PCR products amplified from bacterial colonies with primer pairs flanking the Not I cloning site (the NotI site was lost when the vector was constructed). The orientation of the inserted universal cassette was verified by sequencing. Plasmids with the universal cassette in the correct orientation were prepared and digested with SmaI restriction enzyme. The completion of SmaI digestion was examined by electrophoresis on a $1.25 \%$ agarose gel. The linearized universal gap repair vectors were cleaned up with a QIAquick ${ }^{\circledR}$ PCR purification kit (Qiagen, Valencia, CA, USA), quantitated with PicoGreen ${ }^{\circledR}$ double-stranded (dsDNA) Quantitation Reagent (Molecular Probes, Eugene,

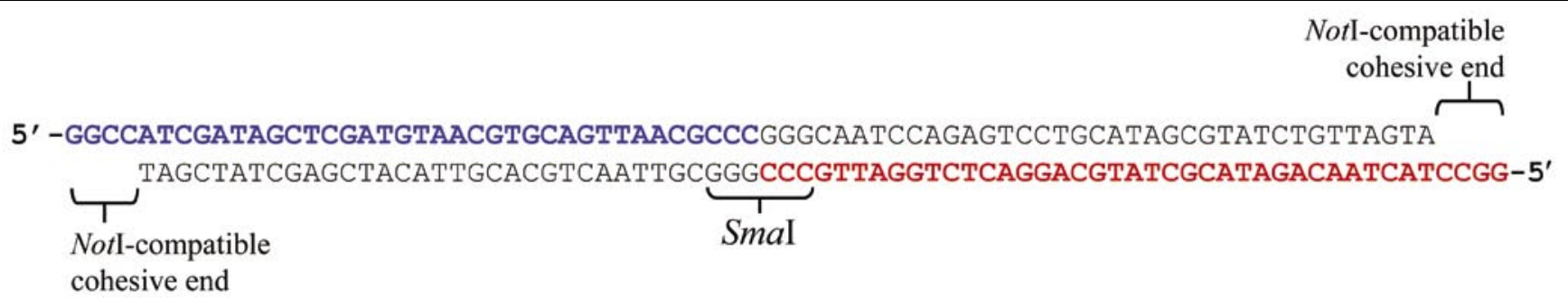

Figure 1. Annealed universal linker. The universal linker contains two half sites jointed by a SmaI restriction site. The universal linker derived from randomly selected codons is designated L306, an internal laboratory reference number. NotI-compatible cohesive ends and SmaI sites of the annealed universal linker are indicated. The universal linker is designed to have its codons in frame with the center of the NotI and SmaI sites. The $5^{\prime}$ half of the upper universal linker oligonucleotides (in blue) is used to design upper hybrid primers of selected genes. The $5^{\prime}$ half of the lower universal linker oligonucleotides (in red) is used to design lower hybrid primers of selected genes. 
OR, USA), and diluted to a working concentration of $0.1 \mu \mathrm{g} / \mu \mathrm{L}$.

\section{Rats and Mice}

N2 rats of a cross between Brcal knockout and Sprague Dawley (SD) rats and $\mathrm{N} 2$ rats of a cross between Brca 2 knockout and SD rats were used for this study. These N2 rats carry either two alleles of the wild-type Brcal or Brca2 gene or carry one mutant allele, based on previous experiments that had been confirmed both by the yeast truncation mutation assay with gene-specific gap repair vectors and by sequencing yeast clones. The Brcal mutant allele contains a $\mathrm{T}$ to $\mathrm{C}$ mutation at nucleotide 1238 of intron 21 in the splicing branch site, causing a deletion of exon 22 (74 bp) in mature Brcal mRNA and a reading frame shift (1), resulting in premature translation termination. The Brca2 mutant allele contains a $\mathrm{T}$ to $\mathrm{A}$ transversion mutation at nucleotide 4254 that converts a tyrosine codon (TAT) into a stop codon (TAA). F1 mice of a cross between Ataxia-telangiectasia mutated (Atm) and Adenomatosis polyposis coli multiple intestinal neoplasia $\left(A p c^{\mathrm{Min} /+}\right)$ mice (5) were included in our study to examine the applicability of the universal gap repair vectors in assaying different species. The Min mice (6) carry a nonsense mutation in the $A p c$ gene at codon 850 (a T to A mutation at nucleotide 2549).

\section{DNA/RNA Extraction}

DNA and/or RNA were isolated from Brcal and Brca2 N2 rats ( $n=8$ and 14, respectively) and $\left(A t m \times A p c^{M i n /+}\right) \mathrm{F} 1$ mice $(n=10)$. To isolate DNA, small sections of rat tails or spleens of (Atm $\times$ $\left.A p c^{M i n /+}\right) \mathrm{F} 1$ mice were digested overnight at $55^{\circ} \mathrm{C}$ in $500 \mu \mathrm{L}$ of genomic lysis buffer consisting of $20 \mathrm{mM}$ Tris$\mathrm{HCl}, \mathrm{pH} 8.0,150 \mathrm{mM} \mathrm{NaCl}, 100 \mathrm{mM}$ EDTA, and $1 \%(\mathrm{w} / \mathrm{v})$ of sodium dodecyl sulfate (SDS). Two hundred microliters of PUREGENETM protein precipitation solution (Gentra Systems, Minneapolis, MN, USA) were mixed with the lysate solution and centrifuged at $13,000-16,000 \times g$ for $3 \mathrm{~min}$ to separate the phases. DNA in the clear supernatant was precipitated with isopropanol, washed, and resuspended in 100-500 $\mu \mathrm{L}$ water. Total RNA was isolated from rat tails by homogenization in RNABee $^{\mathrm{TM}}$ reagent (Tel-Test, Friendswood, TX, USA) using a Polytron ${ }^{\circledR}$ PT10-35 (Kinematica, Cincinnati, OH, USA). The samples were then extracted with chloroform. RNA in the clear aqueous layer was precipitated with isopropanol and washed with $80 \%$ ethanol. RNA pellets were resuspended in $30-50 \mu \mathrm{L}$ RNA suspension solution (RNA Storage Solution; Ambion, Austin, TX, USA).

\section{Reverse Transcription and PCR}

Oligonucleotide primers used in this report are listed in Table 1 . To synthesize cDNA for Brcal and Brca2, $2 \mu \mathrm{g}$ of tail total RNA were mixed with $0.25 \mu \mathrm{g}$ of Brcal-LP5593 or Brca2-LP6331 primer, $2 \mu \mathrm{L}$ of $10 \mathrm{mM}$ dNTPs, and RNase-free water to a volume of $12 \mu \mathrm{L}$, and denatured at $65^{\circ} \mathrm{C}$ for $5 \mathrm{~min}$. The denatured mixtures were cooled to $4^{\circ} \mathrm{C}$, and then supplemented with $8 \mu \mathrm{L}$ of ThermoScript $^{\mathrm{TM}}$ RT Mixture (here RT stands for reverse transcriptase; Invitrogen, Carlsbad, CA, USA), and incubated for 70 min at $50^{\circ}-55^{\circ} \mathrm{C}$. The ThermoScript RT mixture consisted of $4 \mu \mathrm{L}$ of $5 \times$ cDNA synthesis buffer, $1 \mu \mathrm{L}$ of $100 \mathrm{mM}$ dithiothreitol (DTT), $1 \mu \mathrm{L}$ of RNaseOUT ${ }^{\mathrm{TM}}$ (40 U/ $\mu \mathrm{L}$; Invitrogen), $1 \mu \mathrm{L}$ of RNase free water, and $1 \mu \mathrm{L}$ of ThermoScript RT (15 U/ $\mu \mathrm{L})$. PCR was performed with 0.5 $\mu \mathrm{L}$ of the cDNA product or approximately $0.1 \mu \mathrm{g}$ of genomic DNA with $1 \mathrm{U}$ of Herculase $^{\circledR}$ Enhanced DNA polymerase (Stratagene, La Jolla, CA, USA) in $20 \mu \mathrm{L}$ reactions containing $1 \times$ Herculase buffer, $0.2 \mathrm{mM}$ dNTP, and $400 \mathrm{nM}$ of hyb-UP and hyb-LP primers (Qiagen Operon, Alameda, CA, USA) for each gene (Table 1). Reaction conditions for rat Brcal and Brca 2 fragments were $95^{\circ} \mathrm{C}$ for $3 \mathrm{~min}$, followed by 32 cycles of $30 \mathrm{~s}$ at $95^{\circ} \mathrm{C}, 40$ $\mathrm{s}$ at $58^{\circ} \mathrm{C}$, and $4 \mathrm{~min}$ at $72^{\circ} \mathrm{C}$, followed by $5 \mathrm{~min}$ at $72^{\circ} \mathrm{C}$. For the mouse $A p c$ fragment, the cycling conditions were similar, except $2 \mathrm{~min}$ was used for the $72^{\circ} \mathrm{C}$ extension step. The quality of PCR products was examined by electrophoresis on a $1.25 \%(w / v)$ agarose gel.

\section{Yeast Truncation Mutation Assay}

yIG397 (7) yeast cells were prepared as previously described (1). For 
each transformation, $30 \mu \mathrm{L}$ of yeast cell suspension were mixed with $10 \mathrm{ng}$ of linearized gap vector, $25 \mu \mathrm{g}$ of salmon sperm carrier DNA, $150 \mu \mathrm{L}$ of LiOAc/ TE/PEG solution [0.1 M lithium acetate/10 mM Tris- $\mathrm{HCl}, \mathrm{pH} 8.0,1 \mathrm{mM}$ EDTA/40\% (w/v) polyethylene glycol (PEG)], and 1-5 $\mu \mathrm{L}$ of unpurified rat Brcal, Brca2, or mouse Apc PCR product. The mixture was incubated for 30 $\min$ at $30^{\circ} \mathrm{C}$, and then heat-shocked for $15 \mathrm{~min}$ at $42^{\circ} \mathrm{C}$. Transformants were pelleted by centrifugation at $830 \times g$ for $5 \mathrm{~min}$, resuspended in water, and plated on synthetic minimal medium lacking leucine and supplemented with low adenine $(5 \mu \mathrm{g} / \mathrm{mL})$, and incubated for $72 \mathrm{~h}$ at $30^{\circ} \mathrm{C} \mathrm{(7).} \mathrm{The} \mathrm{plates} \mathrm{were} \mathrm{then} \mathrm{trans-}$ ferred to $4^{\circ} \mathrm{C}$ for further color development. The number of red and white yeast colonies on each plate was determined with a ProtoCOL ${ }^{\mathrm{TM}}$ automated colony counter (Microbiology International, Frederick, MD, USA). Ideally, a mutant will be identified if one half of the yeast colonies are red in color. If nonsense-mediated degradation of the mRNA of the mutant allele occurs, less than half of the colonies in a cDNAbased assay will be red. The number of colonies was confirmed by manual counting if a mutant was detected. The percentages of red colonies to total colonies from duplicate transformations using wild-type DNA or RNA samples were averaged and grouped for background calculation. The percentages of red colonies from samples of heterozygous mutant carriers were also averaged and grouped for calculation.

Synthetic minimal medium was prepared by adding $6.7 \mathrm{~g}$ of yeast nitrogen base without amino acids (BD Biosciences, Palo Alto, CA, USA), $20 \mathrm{~g}$ of glucose (Qbiogene, Carlsbad, CA, USA), and 20 $\mathrm{g}$ of Bacto $^{\mathrm{TM}}$ agar (BD Biosciences) to 1 $\mathrm{L}$ of water and autoclaving for $15 \mathrm{~min}$. The autoclaved medium was cooled to $60^{\circ}-70^{\circ} \mathrm{C}$, and then $10 \mathrm{~mL}$ of $100 \times \mathrm{A}^{5} \mathrm{HT}$ and $10 \mathrm{~mL}$ of $100 \times \alpha \alpha$ dropout were added prior to pouring plates. All amino acids used in preparing $100 \times \mathrm{A}^{5} \mathrm{HT}$ and $100 \times \alpha \alpha$ dropout were obtained from Sigma-Aldrich (St. Louis, MO, USA). The $100 \times \mathrm{A}^{5} \mathrm{HT}$ was prepared by dissolving $50 \mathrm{mg}$ of adenine hemisulfate (Qbiogene), $200 \mathrm{mg}$ of tryptophan, and $200 \mathrm{mg}$ of histidine in $1 \mathrm{~L}$ of water, and sterilized by passing through a $0.22-\mu \mathrm{m}$ filter (Nalgene, Rochester, NY, USA). The $100 \times \alpha \alpha$ dropout was prepared by dissolving $0.4 \mathrm{~g}$ of arginine ( $\mathrm{HCl}), 0.4 \mathrm{~g}$ of methionine, $0.6 \mathrm{~g}$ of isoleucine, $1.0 \mathrm{~g}$ of phenylalanine, $2.0 \mathrm{~g}$ of glutamic acid (sodium salt), $2.0 \mathrm{~g}$ of aspartic acid, 3.0 $\mathrm{g}$ of valine, $4.0 \mathrm{~g}$ of threonine, and $8.0 \mathrm{~g}$ of serine in $1 \mathrm{~L}$ of water at $60^{\circ} \mathrm{C}$, and then filter-sterilizing using a $0.22-\mu \mathrm{m}$ filter.

\section{Sequencing of PCR Products and Plasmid DNA}

To prepare the template for sequencing, $6 \mu \mathrm{L}$ of PCR product were treated with $1 \mu \mathrm{L}$ of ExoSAP-IT ${ }^{\circledR}$ (USB, Cleveland, OH, USA) for $30 \mathrm{~min}$ at $37^{\circ} \mathrm{C}$, followed by $15 \mathrm{~min}$ at $80^{\circ} \mathrm{C}$. Ten micrograms of plasmid DNA prepared with the plasmid kit were cleaned up with a PCR purification kit and eluted in $25 \mu \mathrm{L}$ EB buffer (Qiagen). One microliter of purified PCR product or plasmid DNA was used in a $15-\mu \mathrm{L}$ cycle-sequencing reaction with BigDye ${ }^{\circledR}$ Terminator v3.1 (Applied Biosystems, Foster City, CA, USA). The conditions for cycle sequencing were $95^{\circ} \mathrm{C}$ for $3 \mathrm{~min}$, followed by 32 cycles of $95^{\circ} \mathrm{C}$ for $30 \mathrm{~s}$ and $58^{\circ} \mathrm{C}$ for $2 \mathrm{~min} 30$ s, followed by $72^{\circ} \mathrm{C}$ for $7 \mathrm{~min}$.

\section{RESULTS AND DISCUSSION}

The universal gap repair vector with linkers of randomly selected codons was engineered, verified by sequenc-

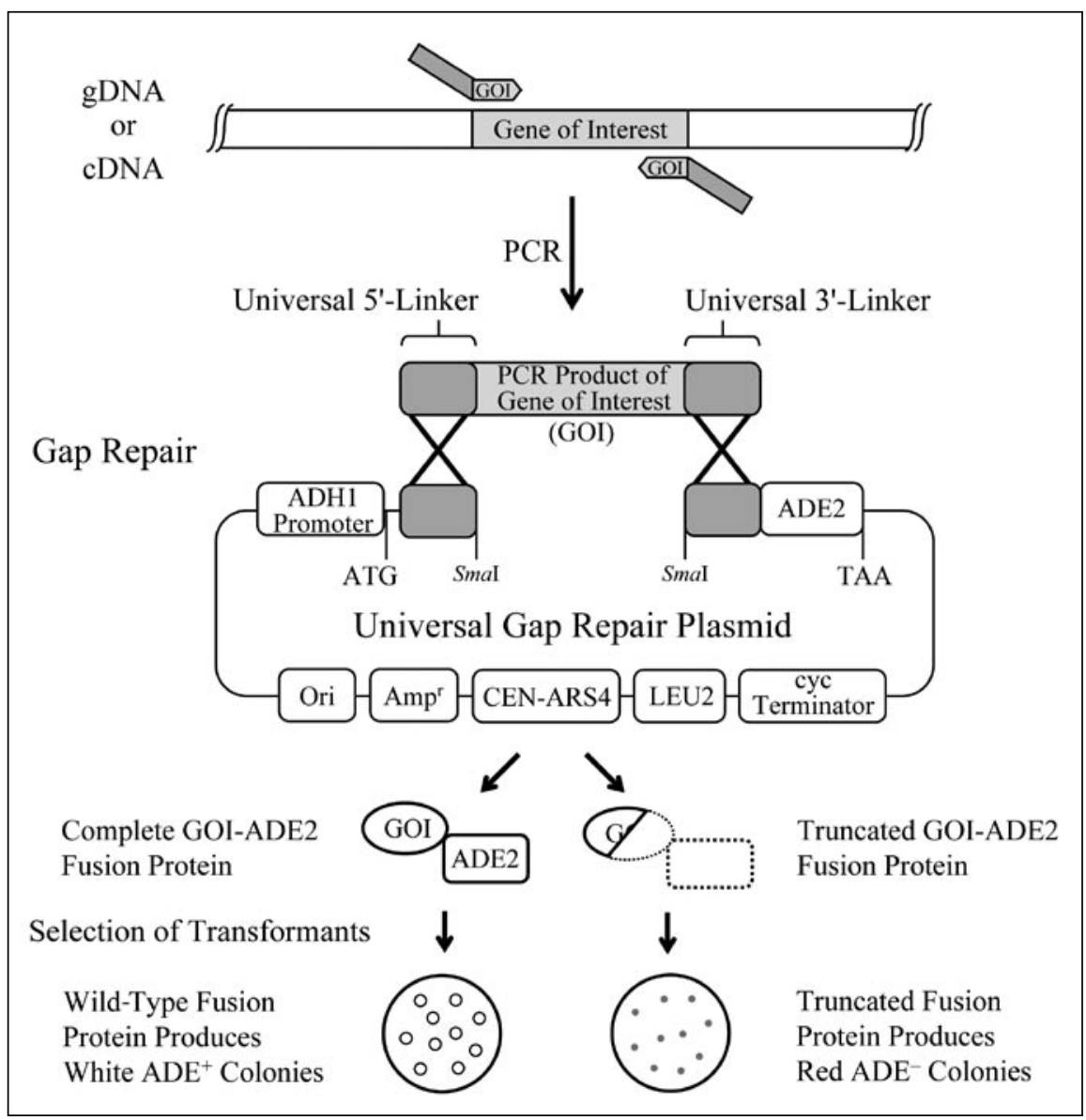

Figure 2. Diagram of genomic DNA (gDNA)/cDNA truncation assays using a universal gap repair vector. gDNA or cDNA fragments of interest are PCR amplified with chimeric oligonucleotide primers. The $3^{\prime}$ termini of chimeric primers are sequences derived from a gene of interest (GOI) that will specify the PCR product. The $5^{\prime}$ termini of the chimeric primers are homologous to the linkers in the universal gap repair vector. Following co-transformation into the yeast cells, the GOI fragment is cloned into the universal gap repair vector by homologous recombination. A wild-type gene fragment will produce a functional fusion protein with the $A D E 2$ gene of the vector and forms large white yeast colonies when plated on selective medium. A gene fragment with a truncation mutation will not form a functional fusion protein, and approximately $50 \%$ of the yeast colonies will be small and red. 
ing, and purified in large quantities. Test transformation of yeast cells with the circular universal gap repair vector gave rise to only large white colonies on selective medium, as expected.

Brcal and Brca2 rat knockouts were tested with the new vectors using the yeast truncation assay (Figure 2). In addition, spleen DNA samples from (Atm $\times$ $\left.A p c^{M i n /+}\right) \mathrm{F} 1$ mice (5) were also examined for the applicability of our newly developed universal gap repair vector. The $\mathrm{Min}$ mouse is known to carry a Leu850Stop ( $\mathrm{T}$ to A) truncation mutation in the Apc gene (6), whereas the Atm mouse has wild-type Apc. Yeast truncation mutation assays using the universal gap repair vector pLSL306 containing randomly selected codons (Figure 1) gave a low background (Figure 3, A, C, E, G, and I) that was clearly distinguished from those in which a mutant allele was present (Figure 3, B, D, F, H, J).

Using the pLSL306 universal gap repair vector, the background of red colonies in wild-type samples ranged from $4.6 \%-9.2 \%$ for genomic DNA assays and $9.6 \%-12.3 \%$ for the cDNA assays (Table 2). These background levels are comparable to previous runs of cDNA assays using Brcal and Brca2 gene fragment-specific gap vectors, $12.2 \%$ and $15.3 \%$, respectively (1). The background levels for the mouse Apc genomic DNA assay ranged from $4.6 \%-6.8 \%$. A universal gap repair vector system with a comparable red colony background (4.8\% to $12.7 \%$ ) has also been developed by Kataoka et al. (8) in which the linker sequences were derived from sequences of their gap vector and the ADE2 reporter gene. The background for genomic DNA assays using the pLSL306 universal gap repair vector is higher than that in assays using Brca2-specific gap repair vectors, which ranges from $0.5 \%$ to $1.1 \%$ (1). However, this would not hamper the ability of the assay to identify mutant genes. The percentage of red colonies for PCR products from any of the mutant allele carriers ranged from $45.5 \%$
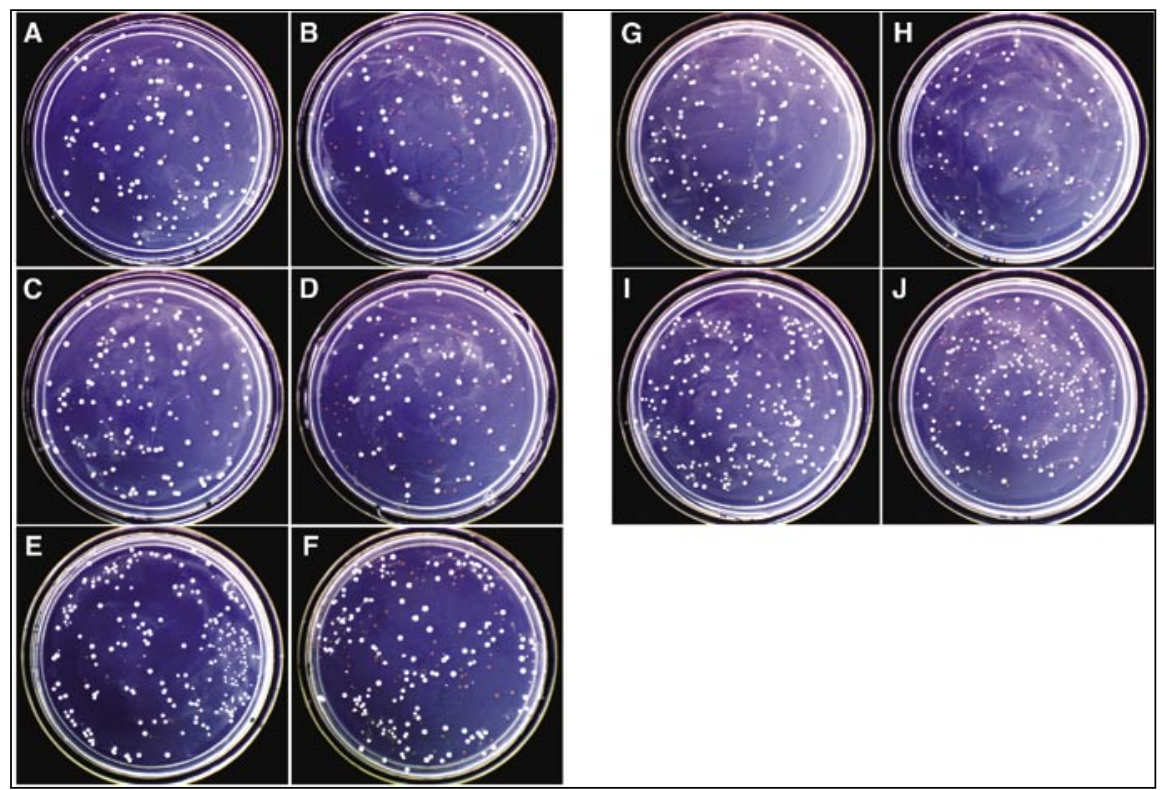

Figure 3. Yeast transformation plates. Two Brcal cDNA fragments (nucleotides 3982-5568 and 5038-5568) and one Brca2 cDNA fragment (nucleotides 3436-5265) of the rat were analyzed using the cDNA-based yeast truncation assays. The rat Brca2 fragment (nucleotides 3436-5265) and a mouse Adenomatosis polyposis coli (APc) genomic DNA fragment (nucleotides 2182-3129) were also analyzed using the genomic DNA-based yeast truncation assays. Yeast cells transformed with both the pLSL306 universal gap repair vector and reverse transcription PCR (RT-PCR; cDNA) or PCR (genomic DNA) products were plated on selective medium. (A and B) Rat Brcal cDNA nucleotides 3982-5568; (C and D) rat Brcal cDNA nucleotides 5038-5568; (E and F) rat Brca2 cDNA nucleotides 3436-5265; (G and H) rat Brca2 genomic DNA nucleotides 3436-5265; (I and J) mouse Apc genomic DNA nucleotides 2182-3129. In truncation assays using cDNA (plates A, C, and E) or genomic DNA (plates G and I) of rats or mice with two wild-type alleles, yeast transformants are mostly large white colonies $(>90 \%)$. With cDNA (plates B, D, and F) or genomic DNA (plates $\mathrm{H}$ and $\mathrm{J}$ ) derived from rats or mice carrying one truncation mutation allele, the resultant plates contain almost equal numbers of red and white colonies. 
Table 2. Yeast Truncation Mutation Assay

\begin{tabular}{|c|c|c|c|}
\hline \multirow[t]{2}{*}{ Gene Fragment } & \multirow[t]{2}{*}{$\begin{array}{l}\text { Size } \\
\text { (bp) }\end{array}$} & \multicolumn{2}{|c|}{$\begin{array}{c}\text { Mean Number of Red Colonies }{ }^{a} \\
(\%)\end{array}$} \\
\hline & & $\mathrm{Wt} / \mathrm{Wt}^{\mathrm{b}}$ & Mut/Wtc \\
\hline Rat Brca1 cDNA 3982-5568 & 1587 & $12.3 \pm 1.9 \%(n=6)$ & $46.6 \pm 4.2 \%(n=2)$ \\
\hline Rat Brca1 cDNA 5038-5568 & 531 & $10.9 \pm 1.7 \%(n=6)$ & $45.5 \pm 4.6 \%(n=2)$ \\
\hline Rat Brca2 cDNA 3436-5265 & 1830 & $9.6 \pm 1.8 \%(n=5)$ & $47.7 \pm 2.4 \%(n=9)$ \\
\hline \multirow[t]{2}{*}{ Rat Brca2 gDNA 3436-5265 } & 1830 & $5.9 \pm 0.6 \%(n=5)$ & $48.8 \pm 1.6 \%(n=5)$ \\
\hline & & $9.2 \pm 2.8 \%(n=5)$ & $49.2 \pm 3.3 \%(n=9)$ \\
\hline \multirow[t]{2}{*}{ Mouse Apc gDNA 2182-3129 } & 948 & $4.6 \pm 1.2 \%(n=5)$ & $48.8 \pm 1.0 \%(n=5)$ \\
\hline & & $6.8 \pm 1.9 \%(n=5)$ & $47.4 \pm 1.9 \%(n=5)$ \\
\hline $\begin{array}{l}\text { gDNA, genomic DNA. } \\
\text { aMean }( \pm S D) \text {. } \\
\text { bHomozygous wild-type. } \\
\text { cHeterozygous mutant. }\end{array}$ & & & \\
\hline
\end{tabular}

to $49.2 \%$ for either the genomic DNA or cDNA assays (Table 2). These percentages are also comparable to those detected in the gene-specific gap vector system at $44.3 \%$ for our rat knockout line Brcal cDNA fragment 3 and $45 \%$ for our rat knockout line Brca2 genomic DNA fragment 2 (1).

The difference in sizes of PCR products $(0.53$ to $1.83 \mathrm{~kb})$ does not appear to contribute significantly to the variation of the background (Table 2). However, we do recommend limiting the size of the PCR product to approximately 2.0 $\mathrm{kb}$ because of our our observation of a decreased efficiency in PCR amplification of larger fragments using hybrid primers (K.S. Chen, Y. Zan, and M.N. Gould, unpublished data). The lower efficiency of amplifying larger PCR products with high-fidelity DNA polymerase may hamper the subsequent yeast truncation mutation assays. The variation of the background red colony formation between the cDNA and genomic DNA assays of Brca2 fragment 2 (nucleotides 3436-5265) is also minimal (Table 2 ), with the cDNA assay background slightly higher, most likely attributed to nucleotide misincorporation introduced during the reverse transcription step. Similar findings were also observed using customized vectors (1).

In summary, the universal gap repair vector we developed in this study satisfies the criteria proposed above. First, the universal vector can be readily used for screening different genes without further modification except linearization before use. Second, it works well in both the cDNA and genomic DNA assays. Third, it can be used for screen- ing gene fragments derived from different species.

By combining two efficient technologies, ENU-induced mutagenesis and the yeast-based truncation mutation assay, we successfully produced suppressor genes Brcal and Brca2. We report here the development of a universal gap repair vector that will work equally efficiently in cDNA and genomic DNA assays with PCR products of various sizes and origins. With this new universal gap repair vector, it is feasible to do high-throughput screening for multiple targeted genes in order to select animals with function-inactivating mutations.

\section{ACKNOWLEDGMENTS}

We thank Dr. Amy Moser for providing us with $\left(\mathrm{Atm} \times \mathrm{Apc}^{\mathrm{Min} /+}\right) \mathrm{Fl}$ mouse tissues; Dr. Laurie Shepel for proofreading and editing of the manuscript; Ms. Jill Haag and Dr. Yunhong Zan for their excellent technical support. This study was supported by NIH-CA101201 (to M.N.G.).

\section{COMPETING INTERESTS STATEMENT}

The authors declare that they have no competing interests.

\section{REFERENCES}

1.Zan, Y., J.D. Haag, K.-S. Chen, L.A. Shepel, D. Wigington, Y.R. Wang, R. Hu, C.C. two knockout rats for the breast cancer
Lopez-Guajardo, et al. 2003. Production of knockout rats using ENU mutagenesis and a yeast-based screening assay. Nat Biotechnol. 21:645-651.

2.Justice, M.J., J.K. Noveroske, J.S. Weber, B. Zheng, and A. Bradley. 1999. Mouse ENU mutagenesis. Hum. Mol. Genet. 8:1955-1963.

3.Noveroske, J.K., J.S. Weber, and M.J. Justice. 2000. The mutagenic action of N-ethyl$\mathrm{N}$-nitrosourea in the mouse. Mamm. Genome 11:478-483.

4.Wheeler, D.L., D.M. Church, A.E. Lash, D.D. Leipe, T.L. Madden, J.U. Pontius, G.D. Schuler, L.M. Schriml, et al. 2001. Database resources of the National Center for Biotechnology Information. Nucleic Acids Res. 29:11-16.

5.Karabinis, M.E., D. Larson, C. Barlow, A. Wynshaw-Boris, and A.R. Moser. 2001. Heterozygosity for a mutation in Brcal or Atm does not increase susceptibility to ENUinduced mammary tumors in $\mathrm{Apc}^{\mathrm{Min} /+}$ mice. Carcinogenesis 22:343-346.

6.Moser, A.R., C. Luongo, K.A. Gould, M.K. McNeley, A.R. Shoemaker, and W.F. Dove. 1995. ApcMin: a mouse model for intestinal and mammary tumorigenesis. Eur. J. Cancer 31A:1061-1064.

7.Flaman, J.M., T. Frebourg, V. Moreau, F. Charbonnier, C. Martin, P. Chappuis, A.P. Sappino, I.M. Limacher, et al. 1995. A simple p53 functional assay for screening cell lines, blood, and tumors. Proc. Natl. Acad. Sci. USA 92:3963-3967.

8.Kataoka, A., M. Tada, M. Yano, K. Furuuchi, S. Cornain, J.-I. Hamada, G. Suzuki, H. Yamada, et al. 2001. Development of a yeast stop codon assay readily and generally applicable to human genes. Am. J. Pathol. 159:1239-1245.

Received 9 March 2004; accepted 12 May 2004.

Address correspondence to Michael N. Gould, Department of Oncology, McArdle Laboratory for Cancer Research, 1400 University Avenue, Madison, WI 53706, USA. e-mail: gould@oncology.wisc.edu 